\title{
Research Paper Export performance of the banana in India
}

\author{
V. G. Landge and S.G. Ingle
}

See end of the paper for authors' affiliations

Correspondence to :

V. G. Landge

Department of Agricultural

Economics, Rajiv Gandhi

College of Agriculture,

Vasantrao Naik Marathwada

Krishi Vidyapeeth,

Parbhani (M.S.) India

Email : sgi10a12p@

gmail.com;

krishnapone@gmail.com

\section{Paper History :}

Received : 20.07.2017;

Revised : 12.01 .2018

Accepted : 26.01.2018
ABSTRACT : Banana is the second most important fruit in India next to mango. India is the second most producer, processor, exporter and consumer of banana. The study was based on secondary data collected from APEDA (Agriculture Produce Export Development Authority). The data pertained to the period of twenty year that is from 1993-94 to 2012-13. The major importing countries of banana from India during the period (1993-94 to 2012-13) UAE (29.53\%), Nepal (20.91\%), Saudi Arab (12.52\%), Bahrain (7.52\%), Kuwait (6.54\%). The linear growth rate of export of banana from India indicated during the overall period . Positive and significant growth rates were seen in UAE, Nepal, Saudi Arab, Bahrain and Kuwait. The compound rates during the overall period were positive and significant. The export earning of Banana from India (in terms of value) during the overall period having the positive and significant.

KEY Words : Banana, export, Growth rate, Performance

How To Cite This Paper : Landge, V.G. and Ingle, S.G. (2018). Export performance of the banana in India. Internat. Res. J. Agric. Eco. \& Stat., 9 (1) : 72-76, DOI : 10.15740/HAS/IRJAES/9.1/72-76. 